ROBERT KULMIŃSKI

Instytut Slawistyki Zachodniej i Południowej

Uniwersytet Warszawski

\title{
JAN PALACH W CZESKIEJ POEZJI ${ }^{1}$
}

\author{
Słowa kluczowe: Jan Palach, samospalenie, bohater, poezja
}

Keywords: Jan Palach, self-immolation, hero, poetry

1.

W czwartkowe popołudnie 16 stycznia 1969 roku około godziny $14.30 \mathrm{w}$ centrum Pragi, w górnej części placu św. Wacława, przed rampą Muzeum Narodowego spalił się Jan Palach; młody dwudziestojednoletni student Wydziału Filozoficznego Uniwersytetu Karola. Uczynił to w geście politycznym, przedstawiając postulaty stricte związane z ówczesną sytuacją panującą w Czechosłowacji. W listach pożegnalnych, podpisanych Pochodnia $\mathrm{nr} 1$, napisał między innymi ${ }^{2}$ : „W związku z tym, że nasze narody znalazły się na skraju beznadziei, zdecydowaliśmy się wyrazić swój protest i obudzić lud tej ziemi w taki właśnie sposób"3. Poza tym żądał zniesienia cenzury i zakazu kolportowania periodyku „Zprávy”4.

Do momentu popełnienia czynu Jan Palach pozostawał postacią anonimową wśród politycznie zaangażowanej młodzieży uniwersyteckiej. Nie można bowiem nazwać czynnym udziałem w ówczesnych wydarzeniach listu napisanego

${ }^{1}$ Artykuł został napisany w ramach realizacji projektu badawczego DEC-2011/01/D/HS3/02113 pt. Samospalenia w wyobraźni społecznej - Ryszard Siwiec, Jan Palach, Akce Pochodeň 2003, finansowanego ze środków Narodowego Centrum Nauki.

${ }^{2}$ Palach napisał cztery listy pożegnalne. Trzy z nich wysłał pocztą - do Związku Pisarzy Czechosłowackich (Svaz československých spisovatelů), Lubomíra Holečka (jednego z przywódców ruchu studenckiego) oraz Ladislava Žižki kolegi z Wyższej Szkoły Ekonomii (Vysoká škola ekonomická), uczelni, w której studiował przed podjęciem nauki na Wydziale Filozoficznym Uniwersytetu Karola. W dwóch ostatnich zawarł prośbę o rozpowszechnienie jego żądań. Czwarty list zabrał ze sobą na miejsce czynu.

${ }^{3}$ Za: Blažek Petr, ,Akce Palach. Edice dokumentů z provenience Ministerstva Vnitra 1969-1974”, in Jan Palach '69, ed. Blažek Petr, Eichler Patrik, Jareš Jakub (Praha: Univerzita Karlova, Togga, Ústav pro studium totalitních režimů, 2009), 471. Tłumaczenia własne, o ile nie zaznaczono inaczej.

${ }^{4}$ Biuletyn wojsk Układu Warszawskiego, wychodzący w Czechosłowacji od końca sierpnia 1969 roku. 
do Lubomíra Holečka, przedstawiciela studentów, w którym zaproponował między innymi okupację budynku radia czechosłowackiego i ogłoszenie w eterze strajku generalnego. Tym bardziej, że pisał w nim, niepewny wartości swojego pomysłu: „Proponuję akcję, która na pierwszy rzut oka może wydawać się głupia (możliwe, że głupia jest) [...]. Jeśli pomysł mój wyda Ci się zbyt szalony, to proszę Cię, żebyś go wyrzucił i nie wspominał o nim" ". Zresztą list ten wrzucony został do pudła z napisem „kuriozity” („osobliwości”) w siedzibie Akademickiej Rady Studentów (Akademická rada studentů) ${ }^{6}$.

Aktywność polityczna Jana Palacha przed dokonaniem samospalenia pozostawała znikoma. Przyjął on bardziej pozycję obserwatora lub co najwyżej anonimowego inspiratora, niż aktywnego uczestnika wydarzeń, choć bez wątpienia świadomy był zachodzących procesów i niezwykle osobiście przeżywał rozwój wydarzeń w Czechosłowacji po inwazji wojsk Układu Warszawskiego. Kumulowanie się owych emocji do wewnątrz musiało spowodować ich dramatyczny upust, uzewnętrzniony w geście samospalenia się. Dopiero właśnie ten akt spowodował, że Jan Palach stał się postacią powszechnie znaną, a jego czyn do dziś pozostaje inspiracją polityczną i społeczną, a także tematem rozważań między innymi filozoficznych, historycznych i socjologicznych oraz motywem utworów literackich oraz muzycznych.

W niniejszych rozważaniach pominę polityczne i społeczne konsekwencje samobójstwa Jana Palacha, aczkolwiek, gdy będzie to niezbędne, kontekst ten zostanie uwzględniony. Skupię się przede wszystkim na analizie poświęconych mu utworów lirycznych. $\mathrm{Z}$ bogatego materiału, zawierającego między innymi wiersz Kazimierza Wierzyńskiego Na śmierć Jana Palacha w Pradze, wygłoszony na antenie Rozgłośni Polskiej Radia Wolna Europa, czy utwór popularnego bułgarskiego poety Valerego Petrova zatytułowany Samospalenie, wybieram jedynie te dzieła, które powstały w Czechosłowacji tuż po dokonaniu przez Jana Palacha samospalenia. Przede wszystkim dlatego, że charakteryzuje je brak dystansu czasowego i kulturowego pomiędzy zdarzeniem a powstaniem utworu. Wszystkie wybrane wiersze zostały napisane krótko po śmierci Jana Palacha, a są utworami czeskich poetów i jednego słowackiego, zaangażowanych emocjonalnie w dramatyczne samobójstwo polityczne młodego praskiego studenta, bezpośrednio przeżywających styczniowe wydarzenia 1969 roku.

W konsekwencji w polu mojego zainteresowania pozostają wiersze Miroslava Holuba Praha Jana Palacha oraz Josefa Kainara Bolest at' mi poví opublikowane w tygodniku Związku Pisarzy Czechosłowackich „Listy” 23 stycznia 1969 roku, utwór Jana Skácela Hoř́cí keř, a także wiersz Pavola Horova (wł. Pavol Horovčák) 359.

${ }^{5}$ Blažek Petr, „Akce Palach. Edice dokumentů z provenience Ministerstva Vnitra 1969-1974”,

${ }^{6}$ Por. Petr Zídek, Palach chtěl obsadit rozhlas, http://www.lidovky.cz/palach-chtel-obsadit-rozhlasdgw-/zpravy-domov.aspx?c=A090109_143339_ln_domov_hrn (acc. 2.09.2016). 
Malé rekviem za Jána Palacha a iných, oba wydane również w czasopiśmie „Listy”, odpowiednio 6 i 13 lutego, a także napisany 30 stycznia 1969 roku przez Jana Zábranę wiersz zatytułowany První (Noc v Tatrách) ${ }^{7}$. Pomijam wiersze naśladowcy Jana Palacha, Jana Zajíca Janu Palachovi oraz Poslední, bez względu na ich wartość literacką, ponieważ pierwotnie nie były one przeznaczone do druku. Zajíc pisał je tylko dla siebie i prawdopodobnie, gdyby nie dokonał samospalenia, to pozostałyby nieopublikowane do dziś.

2.

W wyżej wymienionych utworach interesują mnie przede wszystkim sposoby artykułowania heroizacji postaci i czynu Jana Palacha. Sa bowiem te wiersze częścią dyskursu bohaterskiego, współtworzą narrację heroiczną, przedstawiają samospalonego w glorii chwały, jako niezaprzeczalnego bohatera, ofiarę poniesioną na ołtarzu idei.

Niemniej, niezaprzeczalnie mamy w tym wypadku do czynienia z lirycznym wyobrażeniem śmierci samobójczej, a właściwie ze szczególnym opisem samobójstwa altruistycznego wynikającego ze zbyt silnego związku jednostki ze społeczeństwem ${ }^{8}$. Émile Durkheim co prawda rozważał wyróżnienie kategorii samobójstw heroicznych, czynów, które zwykło się uważać za szlachetne, a nawet godne podziwu, i często nie uznawanych za akty zabicia samego siebie ${ }^{9}$. Jednak ostatecznie pomysł ten odrzucił z powodu braku możliwości rozróżnienia wartości motywu popełnienia samobójstwa: „Kiedy motyw [samobójstwa - R.K.] przestaje być dostatecznie godny pochwały, aby czyn będący jego skutkiem można było nazwać samobójstwem?" - pytał ${ }^{10}$. Analogicznie rozumował już wcześniej Tomáš Garrigue Masaryk w wydanej po raz pierwszy w 1881 roku w Wiedniu książce Der Selbstmord als soziale Massenerscheinung der Gegenwart ${ }^{11}$. Ponad samobójstwem w węższym znaczeniu (,sebevražda”) ${ }^{12}$ stawiał on ofiarę dokonaną z własnego życia („sebeobětování”), chociaż, jak konkludował, logicznie należałoby ją zaliczyć do samobójstwa w szerszym tego słowa znaczeniu ${ }^{13}$. Aczkolwiek zarówno Masaryk, jak i Durkheim dostrzegają różnicę pomiędzy samobójstwem a odebraniem sobie życia w imię wyższych celów, to ostatecznie obaj zgodnie stwierdzają, że każdy taki czyn strukturalnie samobójstwem pozostaje.

\footnotetext{
${ }^{7}$ Jan Zábrana, „První (Noc v Tatrách)”, in idem, Zed' vzpominek (Brno: Atlantis, 1992), 12.

${ }^{8}$ Vide Émile Durkheim, Samobójstwo (Warszawa: Oficyna naukowa, 2006), 275.

${ }^{9}$ Ibidem, 303.

${ }^{10}$ Ibidem.

${ }^{11}$ Pierwsze czeskie wydanie tej książki, zatytułowane Sebevražda hromadným jevem společenským moderní osvěty pochodzi z 1904 roku.

${ }^{12}$ Samobójstwo w szerszym znaczeniu (,sebezabití”) było według Masaryka ściśle związane z każdą nienaturalną śmiercią.

${ }^{13}$ Tomáš Garrigue Masaryk, Sebevražda hromadným jevem společenským moderní osvěty (Praha: Jan Laichter, 1904), 3.
} 
Rozważana różnica jest kluczowa, jak się wydaje, nie tyle dla samej istoty samobójstwa, ile przede wszystkim dla jego postrzegania - zarówno przez samobójcę, jak i pozostałą część społeczeństwa, a w tym wypadku przez poetów opisujących ten czyn w swoich utworach. Szczególnie dotyczy to tych społeczności, w imię wartości których ktoś odbiera sobie życie. Samobójca staje się wtedy ofiarą, nie popełnia samobójstwa, tylko poświęca swoje życie, nie działa jak jednostka odizolowana od wspólnoty, ale jest integralną częścią tego społeczeństwa, silnie z nim związaną, na tyle, aby darować w imię jego wartości to, co ma najcenniejsze. Analizowane utwory przyjmują wyłącznie taki właśnie punkt widzenia czynu Jana Palacha. W żadnym z tych wierszy Palach nie jest samobójca i właśnie dzięki tej perspektywie możliwa jest heroizacja jego samospalenia.

3.

Przebiega ona zasadniczo w dwóch odmianach. Po pierwsze poprzez sakralizację, odwołanie do symboli religijnych oraz panteonu chrześcijańskich świętych, po drugie przez odniesienia do szeregu bohaterów świeckich. Pierwszy sposób najwyraźniej uwidacznia się już w tytule wiersza Jana Skácela - Gorejący krzew (Hořicí keř). Nawiązanie do sceny z biblijnej Księgi Wyjścia otwiera szeroką przestrzeń interpretacyjną, dzięki wielu symbolicznym odniesieniom zarówno do samego samospalenia, jak i sytuacji panującej ówcześnie w Czechosłowacji. Mojżesz, pasąc owce Jetry - swojego teścia, zapuścił się pewnego dnia w głąb pustyni, pod górę Bożą Horeb (Synaj). Tam ukazał mu się Anioł Boży, sam Jahwe, w płomieniu ognia. „[Mojżesz] widział, jak krzew płonął ogniem, a nie spłonął od niego" $(\mathrm{Wj} 3,3)^{14}$. Jan Palach będący personifikacją gorejącego krzewu zdaje się w wierszu Skácela występować jako sam Jahwe:

(Na každém rohu noci planou ohnivci ${ }^{15}$

Ale tam na poušti je osolené místo

Kde hořel keř za bílého dne).

Na każdym rogu nocy płoną czarki

Ale tam na pustyni jest miejsce słone

Gdzie płonął krzew w biały dzień ${ }^{16}$.

Samospalenie staje się w ten sposób w utworze gestem performatywnym, spektaklem z konkretnym przekazem, rozmową pomiędzy Bogiem a człowiekiem. W żadnym wypadku nie jest samobójstwem, celowym odebraniem sobie życia.

${ }^{14}$ Wszystkie cytaty z Biblii wg: Biblia Tysiąclecia (Poznań: Pallotinum, 2003).

${ }^{15}$ Czes. ohnivec, pol. czarka (Sarcoscyphaceae) - rodzaj grzybów należący do rodziny czarkowatych, o kieliszkowatych owocnikach, mających intensywne, jaskrawe czerwone lub pomarańczowoczerwone zabarwienie wewnętrznej powierzchni miseczki, przypominające kolor płomienia.

${ }^{16}$ Tłumaczenie własne, dosłowne, o ile nie zaznaczono inaczej. 
To akt komunikacji, w którym Palach jako „gorejący krzew”, paralela Boga, oznajmia swój przekaz całemu czechosłowackiemu społeczeństwu, tak jak Jahwe uczynił to Izraelitom poprzez Mojżesza:

\footnotetext{
Pan mówił: „Dosyć napatrzyłem się na udrękę ludu mego w Egipcie i nasłuchałem się narzekań jego na ciemiężców, znam więc jego uciemiężenie. Zstąpiłem, aby go wyrwać z ręki Egiptu i wyprowadzić z tej ziemi do ziemi żyznej i przestronnej, do ziemi, która opływa w mleko i miód, na miejsce Kananejczyka, Chetyty, Amoryty, Peryzzyty, Chiwwity i Jebusyty. Teraz oto doszło wołanie Izraelitów do Mnie, bo też naocznie przekonałem się o cierpieniach, jakie im zadają Egipcjanie. Idź przeto teraz, oto posyłam cię do faraona, i wyprowadź mój lud, Izraelitów, z Egiptu" [Wj, 3, 7-10].
}

List pozostawiony przez Jana Palacha, jak już wspomniałem, zawierał bardzo konkretne żądania, niemniej poza nimi samospalenie miało obudzić społeczeństwo czechosłowackie z normalizacyjnego marazmu, w który zaczęło popadać po inwazji wojsk Układu Warszawskiego 21 sierpnia 1969 roku. Jak Mojżesz miał wyprowadzić Izraelitów z niewoli egipskiej, tak Palach, w oczach podmiotu lirycznego, swoim czynem wskazywał drogę do uwolnienia się spod jarzma okupantów.

Niemniej osoba mówiąca w wierszu nie ma tu wątpliwości - prorok poprowadził lud do Ziemi Obiecanej, samospalenie Palacha pozostanie jednak pustym gestem, Boskim, ale bez odzewu:

\footnotetext{
(Tam ukázal se anděl ř́kal v plameni

A mluvil slova s popelem ted' vítr

Na všechny strany stud náš roznáší).

Tam ukazał się anioł mówił w płomieniach

I mówił słowa z popiołem teraz wiatr

Na wszystkie strony wstyd nasz rozwiewa.
}

Zastosowanie przerzutni wraz $\mathrm{z}$ inwersją $\mathrm{w}$ dwóch ostatnich cytowanych wersach oraz amfibolii - niejasności budowy składniowej, dopuszczającej możliwość dwojakiej interpretacji semantycznej („I mówił słowa z popiołem / z popiołem teraz wiatr”), podkreślać ma jałowość wypowiedzianych słów. Ponadto, pojawiające się w wygłosie tych wersów słowa „wiatr” oraz „roznosi” - obrazują i eksponują rozmiar daremności apelu „gorejącego krzewu”. Zresztą już we wcześniejszym fragmencie utworu - odwołując się do jednego z najbardziej rudymentarnych symboli chrześcijańskich - gołębicy, symbolu Ducha Świętego, podmiot liryczny zapowiada, że poniesiona ofiara będzie bezowocna:

(Kde hořel keř za bílého dne

Tam popelavé peří ztrácí holubice).

Gdzie płonął krzew w biały dzień

Tam popielate pióra straci gołębica. 
Duch Święty, nazywany też w Ewangelii wg św. Jana „Duchem Prawdy” $(\mathrm{J} 15,27)$ symbolicznie zostaje pozbawiony swojego charakteru, bez piór nie uniesie się już nad głowami ludzi, nie zstąpi z nieba. W konsekwencji owoce działania jego łaski (między innymi miłość, radość, pokój, cierpliwość, dobroć) pozostaną słowami rzucanymi na wiatr analogicznie do tych, które wypowiada „gorejący krzew”.

Ten sam wiatr rozsiewa wstyd:

(A mluvil slova s popelem ted' vítr

Na všechny strany stud náš roznáší).

I mówił słowa $z$ popiołem teraz wiatr

Na wszystkie strony wstyd nasz rozwiewa.

Brak reakcji na apel samospalenia przynosi wstyd jest wręcz grzechem przeciwko Duchowi Świętemu, niewybaczalnym, taki, który nigdy nie zostanie odpuszczony:

Dlatego powiadam wam: Każdy grzech i bluźnierstwo będą odpuszczone ludziom, ale bluźnierstwo przeciwko Duchowi nie będzie odpuszczone. Jeśli ktoś powie słowo przeciw Synowi Człowieczemu, będzie mu odpuszczone, lecz jeśli powie przeciw Duchowi Świętemu, nie będzie mu odpuszczone ani w tym wieku, ani w przyszłym [Mt 12, 31-32].

Tok przerzutniowy, pojawiający się dokładnie w połowie utworu Skácela (w siódmym z czternastu wersów), w momencie, gdy podmiot liryczny kontestuje jałowość słów „gorejącego krzewu” i wstyd wynikający z braku odzewu na nie, kończy się w ostatnim wersie, pointującym całość wypowiedzi lirycznej. Nie ma tu już niezgodności między porządkiem składniowo-intonacyjnym a wersyfikacyjnym. Konkluzja zawiera się w jednym wersie, co podkreśla wymowę tych słów i zamyka ostateczne znaczenie utworu:

(Snad jenom Bůh smí hořet uprostřed).

Chyba tylko Bóg może płonąć w centrum.

Zatem samospalenie Jana Palacha nie jest dla podmiotu lirycznego samo w sobie teofanią, aktem objawienia się Boga w świecie, czy nawet hierofanią, przejawieniem się świętości w przestrzeni profanum. Jego czyn nie ma boskiej mocy. Nie dlatego jednak, że sam w sobie nie jest boski, ale dlatego, że nie przyniósł żadnego efektu wskutek braku reakcji ze strony społeczeństwa, do którego został skierowany. Palach Bogiem nie jest, choć podmiot liryczny gest jego do boskich bez wątpienia zaliczył i tylko wstyd mu, że nie znalazł się żaden Mojżesz, który wysłuchawszy „gorejącego krzewu” wyprowadziłby czechosłowackie społeczeństwo z marazmu normalizacji. 
Jan Zábrana w wierszu První (Noc v Tatrách) również odwołuje się do chrześcijańskiego uniwersum. Utwór rozpoczyna się od apostrofy do Jana, a właściwie, jak wyjaśnia się w wersie następnym, do trzech Janów:

(Jan. Jan. Jan.

Černoústý. Křtitel. Jedno místo z evangelia).

Jan. Jan. Jan.

Czarnousty. Chrzciciel. Jedno miejsce w Ewangelii.

Pierwszy z nich to Jan Palach. Właśnie jemu Zábrana poświęcił swój wiersz. Drugi zaś, Czarnousty, to najprawdopodobniej aluzja do św. Jana Złotoustego, doktora Kościoła bezkompromisowo występującego przeciwko grzechom wiernych. Jeden z trzech oprócz Bazylego Wielkiego i Grzegorza z Nazjanu ojców kościoła, biskup Konstantynopola w obronie moralności nie wahał się otwarcie krytykować rządzących, czym ściągnął na siebie gniew cesarzowej Eudoksji, która doprowadziła ostatecznie do jego wygnania. Samospalenie Palacha było gestem sprzeciwu wobec władzy, ale także przeciwko grzechowi bezczynności czechosłowackiego społeczeństwa. W konsekwencji Palach, postawiony przez podmiot liryczny w jednym szeregu z Janem Złotoustym, zostaje wciągnięty w poczet świętych.

Trzecim z wymienionych Janów jest Chrzciciel, opisywany w Ewangelii św. Mateusza tymi słowy:

W owym czasie wystąpił Jan Chrzciciel i głosił na Pustyni Judzkiej te słowa: „Nawróćcie się, bo bliskie jest królestwo niebieskie”. Do niego to odnosi się słowo proroka Izajasza, gdy mówi: Głos wołającego na pustyni: Przygotujcie drogę Panu, Dla Niego prostujcie ścieżki! [Mt 3,1-3].

Jan Chrzciciel zapowiadał przyjście Zbawiciela, nadejście wyzwolenia od grzechu poprzez ofiarę Chrystusa. Odniesiony do postaci Jana Palacha czyni z Pochodni nr 1 zapowiedź zbawienia Czechosłowacji, a z samospalenia gest ofiarowania się w imię tego zbawienia.

W kolejnym, trzecim wersie, podmiot liryczny kontynuuje ten sposób obrazowania, tym razem poprzez odwołanie się do konkretnego passusu z Ewangelii św. Marka (Mk 15, 34) lub św. Mateusza:

Około godziny dziewiątej Jezus zawołał donośnym głosem: „Eli, Eli, lema sabachthani?”, to znaczy Boże mój, Boże mój, czemuś Mnie opuścił? Słysząc to, niektórzy ze stojących tam mówili: „On Eliasza woła". Zaraz też jeden z nich pobiegł i wziąwszy gąbkę, napełnił ją octem, włożył na trzcinę i dawał Mu pić. Lecz inni mówili: „Poczekaj! Zobaczymy, czy przyjdzie Eliasz, aby Go wybawić”. A Jezus raz jeszcze zawołał donośnym głosem i wyzionął ducha [Mt 27, 46-50].

Nawiązanie do najważniejszego dla chrześcijan wydarzenia podkreślone zostało w wierszu instrumentacją głoskową oraz paralelizmem składniowym. 
Inkrustacja melodyczna, jednego z najkrótszych wersów w utworze, nadaje mu charakterystycznego rytmu, wyróżniającego właśnie ten fragment spośród pozostałych:

(Éli, éli - já? I já?)

Eli, eli - ja? I ja?

Zatem to kluczowy moment nie tylko dla religii chrześcijańskiej, ale również dla tego utworu. Początkowe włączenie Palacha do panteonu świętych kulminuje w porównaniu jego czynu do ofiary Chrystusa poniesionej na krzyżu. To już nie tylko męczennik, czy święty, ale zbawca. Tym istotniejsze staje się wygłosowe „ja? I ja?” w tym wersie. Postawione przez podmiot liryczny pytanie zostało niejako zawieszone w próżni, nie wiadomo, do kogo się odnosi? Do Palacha, Boga, czy jest pytaniem, które stawia sobie sam podmiot liryczny? Wyjaśnia się to dopiero w dwóch następnych wersach:

(Zvuk chybí. Prepáčte poruchu.

(Z obrazovky tvé duše neopíšu nic)).

Brakuje dźwięku. Wybaczcie awarię.

(Z ekranu twej duszy nie opiszę nic).

Podmiot liryczny stawia eliptyczne pytanie o to, dlaczego? Dlaczego tak dramatyczna ofiara musiała zostać poniesiona? Jednak pytanie to pozostaje bez odpowiedzi. Jest jedynie pytaniem retorycznym.

W dalszej części wiersza Zábrany postać Jana Palacha porównywana jest do Matki Boskiej Siedmiobolesnej oraz samego Boga:

(Vlasy hořely, vlasy vstávaly k nebi.

Sedmibolestný, starý otec světa).

Włosy płonęły, włosy podnosiły się do nieba.

Siedmibolesny, stary ojciec świata.

Wszystkie cierpienia Matki Boskiej wynikają z dramatów przeżywanych przez jej syna Jezusa Chrystusa. Ostatnie cztery z siedmiu jej boleści związane są z ukrzyżowaniem: spotkanie na Drodze Krzyżowej, ukrzyżowanie i śmierć Jezusa, zdjęcie z krzyża oraz złożenie do grobu. Zatem mamy tu do czynienia z kontynuacją obrazowania samospalenia Jana Palacha w kategoriach ofiary poniesionej w imię zbawienia.

Aczkolwiek już nad grobem Jana Palacha, Jakub Trojan, pastor ewangelicki, który odprawiał uroczystości pogrzebowe Pochodni nr 1 powiedział: „Na ofiarę Jana Palacha spływa, podobnie jak inne, część blasku i odkupieńczej śmierci Jezusa Chrystusa, który oddał swoje życie, żeby uratować wszystkich 
ludzi”17, to z punktu widzenia teologii porównanie takie jest nieuprawnione. Chyba, że ukrzyżowanie Chrystusa występuje jako archetyp ofiary ${ }^{18}$. Tu natomiast (zarówno w wierszu Skácela, jak i Zábrany) Zbawiciel pojawia się jako element (comparans) porównania. W konsekwencji tertium comparationis - to poetycka wizja, sposób heroizacji czynu Jana Palacha, próba uczynienia z niego boskiego aktu ofiarowania się. Obaj poeci starają się włączyć jego czyn w porządek religijny, uczynić z niego gest sakralny, uwznioślić poprzez sakralizację.

Podobnie, niemniej w duchu narodowym, nie zaś religijnym, czyni w swoim utworze Pavol Horov. Zresztą na marginesie trzeba dodać, że to najbardziej udany pod względem poetyckim utwór poświęcony Janowi Palachowi, który powstał w Czechosłowacji tuż po samospaleniu się Pochodni nr 1. „Malé rekviem za Jána Palacha a iných" ma układ sonetu włoskiego o rymach ABAC w tetrastychach oraz DDE w pierwszej i FFE w drugiej tercynie.

W wersach refleksyjnych poeta sięga do archetypu ojczyzny-matki, która modli się nad ofiarą swojego syna:

(Ako tromb v žilách sŕdc páli tá živá fakl'a

Matka Vlast' k modlitbe si osirelá kl'akla

Otčenáš Sloboda

Noazaj zostane len popol po plameni

A či ako fénix sa vznesie zas oživený

Duch jeho národa).

Jak skrzep w żyłach serc parzy ta żywa pochodnia

Matka Ojczyzna do modlitwy osierocona klęka

Ojcze nasz Wolność

Naprawdę zostanie tylko popiół po płomieniu

I czy jak Feniks powstanie znów ożywiony

Duch jego narodu.

Palach nie staje się bogiem lub świętym, jest raczej bohaterem narodowym, który poprzez swój czyn wskrzesi zagubionego ducha narodu. Już w pierwszym wersie podmiot liryczny zaznacza, że nie będzie płakał, raczej zaciśnie zęby i przez łzy zacznie się buntować:

(Já plakat' nebudem nie radšej zatnem zuby

Tŕpky sl'z prehltnem vzlyk plaču pretne vzdor).

Ja płakać nie będę nie raczej zacisnę zęby

Cierpkie łzy przełknę szloch płaczu przetnie bunt.

${ }^{17}$ Josef Sádecký, Živé pochodně (Zurich: Konfrontation, 1980), 26.

${ }^{18}$ Jindřich Šrajer, Suicidum, sebeobětování nebo mučednictví? (Praha - Kroměříž: Triton, 2009), 195. 
Oba cytowane wersy mają paralelną budowę. Część przedśredniówkowa semantycznie odnosi się do przełamania smutku, żalu po stracie, natomiast pośredniówkowa dotyczy oporu, który w ówczesnej sytuacji politycznej jest jednoznacznie skierowany przeciwko panującemu porządkowi politycznemu. Zatem analogiczny komunikat powtórzony został przez podmiot liryczny dwukrotnie już na samym początku utworu, w pierwszych dwóch jego wersach. W ten sposób wzmocniona została część refleksyjna sonetu. Podmiot liryczny bowiem opisuje swoją reakcję na samospalenie się Jana Palacha (zaczynając od nagłosowego „Ja” w pierwszym wersie), reakcję zamienioną następnie w refleksję w drugiej części utworu (jak w klasycznym sonecie włoskim). W konsekwencji Palach staje się autentycznym, potwierdzonym w działaniu podmiotu lirycznego zarzewiem wskrzeszenia ducha narodowego. Niejako sam podmiot liryczny staje się dowodem skuteczności ofiary Jana Palacha.

Co interesujące, utwór Horova szczególny nacisk kładzie przede wszystkim na konsekwencje czynu Jana Palacha i to właśnie owe konsekwencje podnosi do rangi bohaterskich - nie samospalenie się, ale podniesienie się z popiołów. Samego czynu zaś podmiot liryczny nie poddaje ocenie. W refrenie powtarzajaccym się w tetrastychach części opisowej sonetu osoba mówiąca w wierszu oznajmia:

(Ked' láska bezmocná sa s desnou smrt'ou snúbi

Koho chceš obvinit'

[...]

Ked' láska bezmocná sa s desnou smrt'ou snúbi

Nopomôže ti nič).

Kiedy miłość bezradna ze straszliwą śmiercią się spotyka

Kogo chcesz obwiniać

$[\ldots]$

Kiedy miłość bezradna ze straszliwą śmiercią się spotyka

Nie pomoże ci nic.

Ponownie mamy tu do czynienia z odwołaniem się do wyobrażenia archetypicznego. Tym razem połączenia miłości i śmierci, Erosa i Tanastosa, które obrazuje krąg życia. Śmierć jest w nim pożywką dla nowego istnienia. To nie biblijne przypomnienie o śmiertelności człowieka: „,[...] bo prochem jesteś i w proch się obrócisz!” (Rdz 3,19), raczej freudowska refleksja na temat uzupełniających się instynktów kierujących życiem człowieka. Życie wyrasta ze śmierci. Co więcej, to właśnie śmierć pozwala na to, aby nowe życie wyrosło, aby cykl rozpoczął się od nowa.

Spotkanie się tych dwóch instynktów Erosa i Tanatosa, miłości i śmierci, w tym wypadku miłości konkretnej, do ojczyzny - doprowadziło do tragicznego czynu, ale sam czyn nie może podlegać ocenie, ponieważ wyrósł ze spotkania się zbyt silnych instynktów. Jak podkreśla podmiot liryczny, skracając ostatnie wersy 
do części przedśreniówkowej („Kogo chcesz obwiniać” oraz „Nie pomoże ci nic”), nie można za tę sytuację nikogo obwiniać - ale też nic nie da się na nią poradzić.

W wierszu Horova bohaterstwo Jana Palacha nie jest związane z włączeniem go w poczet świętych przez samo dokonanie aktu samospalenia, ale wynika $\mathrm{z}$ realnego oddziaływania tego czynu. Ponadto mowa tu o wartościach narodowych, nie zaś religijnych. Motyw religijny pojawia się jedynie w kontekście ojczyzny, która osierocona modli się modlitwą Ojcze nasz.

Brak odwołania do symboli religijnych charakteryzuje również utwór Josefa Kainara. Bolest at' mi poví to typowa liryka roli:

\author{
(Ani tak nehořím \\ Já plynu \\ Ze žhavých úst jak verš \\ Jako verš o svobodě). \\ Nawet nie płonę \\ Ja płynę \\ Z gorących ust jak wiersz \\ Jak wiersz o wolności.
}

Podmiot liryczny wciela się w rolę samospalonego, wskutek czego to Jan Palach opiewa w tym utworze swój własny czyn, pewny jego wielkości i znaczenia $\mathrm{z}$ rzadko spotykaną w czeskiej poezji wzniosłością. Patos kreowany jest tu przede wszystkim przez warstwę narracyjną i symboliczną wiersza. Mamy zatem w tym utworze odwołanie się do cynowych trumien, w których chowano królów, możnowładców i bogatą arystokrację:

(To já tavím v hrobech těžké rakve z cínu).

To ja roztapiam w grobach ciężkie trumny z cyny.

Juliusz Chrościcki w odniesieniu do kultury staropolskiej pisał:

Do zbytecznie świeckich obrzędów pogrzebu magnackiego i szlacheckiego katolicy zaliczali tradycje: łamania kopii, tarczy i buławy przy katafalku, wjeżdżanie archimimusa na koniu do kościoła, niesienie zbędnych mar przy wyprowadzaniu ciała, prowadzenie koni, udział oddziałów wojskowych, panegiryczne kazania i mowy, bogate stroje zmarłych, cynowe sarkofagi, portrety i herby malowane na srebrnych blachach ${ }^{19}$.

Podobnie było w całej barokowej Europie. Cynowe sarkofagi znamionowały bogactwo, przepych często nawet przez Kościół krytykowany. Podmiot liryczny żarem swojego płomienia owe trumny cynowe roztapia, przyćmiewając niejako blask chwały dawnych władców tego świata.

\footnotetext{
${ }^{19}$ Juliusz Chrościcki, Pompa funebris (Warszawa: PWN, 1974), 259.
} 
Nie inaczej jest w dalszej części utworu, gdzie w przedostatniej zwrotce odnajdujemy opis swoistego wniebowzięcia:

(Ani tak nehořím

Já spíš celý vlaji

Ptáci mě nebesům

celého odevzdají

Mne sarkofágy králů

Přijmou za svého).

Nawet nie płonę

Ja raczej cały faluję

Ptaki do nieba

Całego mnie odnoszą

Sarkofagi królów

Przyjmą mnie za swego.

Ptaki, starożytni wysłannicy bogów, wynoszą płonącą pochodnię do nieba, gdzie już czeka na nią miejsce pośród koronowanych głów. Palach zatem staje się w tym utworze władcą, który spocznie pomiędzy królami. W konsekwencji bohaterem innego rodzaju, niż w analizowanych wcześniej utworach. Jego potęga polega na decydowaniu o losach świata, nie zaś na poświęceniu swojego życia w ofierze.

W innym szeregu stawia Jana Palacha Miroslav Holub w wierszu Praha Jana Palacha:

(A tady dusají Picassovi býci.

A tady pochodují Daliho sloni na pavoučích nohách.

A tady bijí Schöenbergovy bubny.

A tady jede pán de la Mancha.

A tady Karamazovi nesou Hamleta.

A tady je jádro atomu.

A tady je kosmodrom Luny.

A tady stojí socha bez pochodně).

I tutaj tupią byki Picassa.

I tutaj maszerują słonie Dalego na pajęczych nogach.

I tutaj biją bębny Schöenberga.

I tutaj jedzie pan z la Manchy.

I tutaj bracia Karamazow niosą Hamleta.

I tutaj jest jądro atomu.

I tutaj jest kosmodrom Łuny.

I tutaj stoi posąg bez pochodni.

Byki Pabla Picassa to stworzony pomiędzy grudniem 1945 a styczniem 1946 roku cykl jedenastu litografii, ale również bardzo częsty motyw zafascynowanego corridą artysty. Podobnie - kroczące na długich, cienkich nogach słonie 
Slavadora Dalego nie tylko stały się tematem obrazu zatytułowanego Słonie, ale także występują w wielu innych obrazach, chociażby w Kuszeniu św. Antoniego, czy w Śnie wywołanym lotem pszczoły wokół owocu granatu, na sekundę przed przebudzeniem. Motywy obrazów Picassa i Dalego pojawiają się w wierszu Holuba wraz z dodekafoniczną i atonalną muzyką austriackiego kompozytora Arnolda Schoenberga oraz bohaterami powieści Miguela de Cervantesa i Fiodora Dostojewskiego oraz dramatu Williama Shakespeare'a. W tym samym szeregu poeta stawia również jądro atomu oraz kosmodrom Bajkonur, z którego startowały w kosmos sondy „Łuna”. Na końcu tego wyliczenia pojawia się Jan Palach w symbolicznym obrazie pomnika bez pochodni.

Wykorzystanie anafory podkreśla równorzędność wszystkich elementów tego wyliczenia, w którym malarstwo, literatura i muzyka przeplata się z nauką i techniką. Wśród tej swoistej peryfrazy rzeczywistości płonie Jan Palach. Jest on niezbywalną jej częścią. Nie odnajdujemy w tym utworze ani gloryfikacji czynu, ani samej osoby. Raczej spokojne trwanie świata, aż do momentu, w którym w świat ten wkroczyła żywa pochodnia:

(A tady stojí socha bez pochodně.

A tady běží pochodeň bez sochy.

A je to prosté. Kde končí

Člověk, začíná plamen).

I tu stoi pomnik bez pochodni.

I tu biegnie pochodnia bez pomnika.

I to jest proste. Gdzie kończy się

Człowiek, zaczyna się płomień.

To kluczowy moment tego utworu. Statyczny obraz rzeczywistości ulega dynamizacji, wzmocnionej poprzez naruszenie zgody pomiędzy tokiem wersowym i zdaniowym. Wykorzystanie przerzutni podkreśla również istotę granicy człowieczeństwa, o którą pyta podmiot liryczny, umieszczając słowo „człowiek” w nagłosie kolejnego wersu.

Jan Palach swoim czynem przekroczył ową granicę. Dokonał czegoś nadludzkiego i w tym właśnie, zdaniem podmiotu lirycznego, tkwi sens jego bohaterstwa. Niemniej ostateczna konstatacja nie pozostawia żadnych złudzeń:

(A pak v tichu slyšet drmolení

Červů popela. Nebot'

Ty miliardy lidí v podstatě

Drží hubu).

I w ciszy słuchać chrobot

Czerwi popiołu. Ponieważ

Te miliardy ludzi właściwie

nic nie mówią. 
Bohaterstwo Jana Palacha, jego próba obudzenia tego świata, wyrwania go z marazmu, spokojnego trwania pozostała bez odpowiedzi. Jest milczeniem.

4.

Wyraźnie widać, że próby lirycznego zmierzenia się z dramatem śmierci Jana Palacha jednoznacznie wartościują samobójstwo młodego praskiego studenta, choć też nie brak w nich pytań o skutki tego czynu. Sakralizacja polega przede wszystkim na postawieniu znaku równości między Janem Palachem i jego czynem a boskością lub włączenie go w poczet władców. Nawet, jeśli czyn ten nie jest zrozumiany, nie odniósł żadnego skutku, tak, jak w ostatnim z analizowanych wierszy - Praha Jana Palacha Miroslava Holuba. Jedynie Pavol Horov w swoim utworze czyni z Palacha bohatera narodowego, ale też jako jedyny nie ma wątpliwości co do skuteczności samospalenia.

We wszystkich analizowanych utworach samospalenie staje się ofiarą. Palach nie odbiera sobie życia, on składa je w darze dla społeczeństwa. Dar ów o boskiej, królewskiej, ponadludzkiej, narodowej wartości może być niezrozumiały, nie wiadomo, jak na niego zareagować, ale to zawsze dar największej wartości.

\section{JAN PALACH IN THE CZECH POETRY}

\section{Su m m ary}

The article tackles the analysis of lyrical pieces dedicated to Jan Palach. From the extensive material, including inter alia Kazimierz Wierzyński's poem Na śmierć Jana Palacha $w$ Pradze broadcasted by the radio station of Radio Free Europe, or the piece written by a popular Bulgarian poet, Valery Petrov, entitled Self-immolation, I have selected only those works which were created in Czechoslovakia right after Jan Palach had committed self-immolation. The primary reason for such a selection is that they were composed shortly after Palach's act and were written by Czech and Slovakian poets emotionally committed to the dramatic political suicide of a young Prague student and experienced the events of January 1969 directly.

As a consequence, the following works remain in my interest: Miroslav Holub's Praha Jana Palacha and Josef Kainar's Bolest at' mi poví, published in a weekly magazine of the Association of Czechoslovakian Writers "Letters" on $23^{\text {rd }}$ January 1969, Jan Skácel's Hořicí keřr, as well as the poem by Pavol Horov (born Pavol Horovčák) Malé rekviem za Jana Palacha a iných, both published in "Letters" on $6^{\text {th }}$ and $13^{\text {th }}$ February accordingly, and the poem written on $30^{\text {th }}$ January 1969 by Jan Zábrana entitled První (Noc v Tatrách). I do not include in my study poems Janu Palachovi and Poslední written by Jan Palach's follower, Jan Zajíc, because, despite their literary value, they were not initially intended for publishing. Zajíc wrote them only for himself and probably, had he not committed self-immolation, they would not have been published to date.

The aspects I am mainly interested in in the works referred to above are the manners of articulating the heroization of Jan Palach and his act. Indeed, these poems constitute a part of heroic discourse, they create heroic narration and present the self-immolated person in a blaze of glory as an indisputable hero. 